\author{
Klaudia Komenda* \\ Uniwersytet Jagielloński
}

\title{
HARRY POTTER JAKO POTENCJAL EDUKACYJNY, NIE TYLKO DLA DZIECI
}

\begin{abstract}
Harry Potter as an educational potential, not only for children

The process of raising a child is undoubtedly a great challenge for the carer: it involves taking responsibility for the young person, who like a sponge absorbs the knowledge and point of view provided by the educator. It is also a process - in which an adult is forced to make many educational decisions, the sum of which will contribute to what kind of adult the child will become. One of these decisions is to choose the style of upbringing that the carer - more or less consciously manifests towards the child. The following essay provides a short description of these styles, demonstrating their occurrence in the first part of J.K. Rowling's novel about Harry Potter, and also presents some initial reflections on the power relationship between the carer and the child.
\end{abstract}

Key words: childhood, styles of upbringing, Harry Potter

\section{Wprowadzenie}

Wychowanie dziecka to proces niezwykle absorbujący, wymagający wiele uwagi oraz cierpliwości ze strony opiekuna podejmującego się tego zadania. Staje się on bowiem najważniejszą osobą w życiu młodego człowieka, który bezkrytycznie mu ufa i w procesie socjalizacji przyjmuje jego punkt widzenia jako własny.

Harry Potter i kamień filozoficzny z pewnością nie jest pierwszą książką, która przychodzi na myśl w ramach rozważań nad dzieciństwem i wychowaniem, chyba że myślimy w kategoriach rozwijającej wyobraźnię opowieści dla najmłodszych i sposobu na wspólne spędzenie czasu dziecka z opiekunem. Moja pierwsza styczność z serią autorstwa J.K. Rowling miała miejsce około dziesięciu lat temu i wtedy potraktowałam ją właśnie głównie jako rozrywkę. Rzeczywiście, zamiarem autorki zapewne było stworzenie fascynującej historii o młodym czarodzieju, która na wiele lat pochłonie młodych czytelników, a nie dogłębne przeanalizowanie problematyki dorastania, jednakże ponowna lektura książki

\footnotetext{
${ }^{*}$ Studentka studiów II stopnia na kierunku socjologia, Instytut Socjologii UJ.
} 
i głębsza analiza dzieła ukazuje pewne mechanizmy, schematy czy struktury, które Rowling trafnie zdiagnozowała i przeniosła ze świata rzeczywistego do swojej kreacji. Z tego właśnie powodu uważam, że omawiana historia, oprócz pewnej wartości rozrywkowej, może też nieść ze sobą potencjał edukacyjny w kwestii wychowania dzieci oraz pozwolić na spojrzenie na świat z nieco innej perspektywy.

Zanim rozpocznę część główną eseju, chciałabym pokrótce streścić fabułę książki oraz wyjaśnić, kim są niektóre postacie w niej występujące, co znacznie ułatwi odbiór mojej pracy. Harry Potter to główny bohater serii o tym samym tytule. Jest młodym chłopcem, który został bardzo wcześnie osierocony, wskutek czego oddany jest na wychowanie swojemu wujowi i ciotce - Dursleyom, którzy wychowują także swojego syna Dudleya. W swoje jedenaste urodziny Harry dowiaduje się, że nie jest zwykłym chłopcem, ale synem czarodziejów, i on sam również posiada magiczną moc. Miesiąc później wyjeżdża do jednej z najpopularniejszych szkół magii - Hogwartu, gdzie poznaje swoich przyjaciół: Rona Weasleya i Hermionę Granger.

\section{Style wychowania}

Relacje dzieci z dorosłymi w omawianej książce można najogólniej opisać jako dosyć skomplikowane. Młode osoby taktowane są bardzo różnie w zależności od tego, z kim i o czym rozmawiają. Dorośli zachowują się w skrajnie różny sposób w stosunku do dzieci - jedni są wobec nich przyjaźni i otwarci, gotowi służyć pomocą, wsparciem czy odpowiedzieć na nurtujące je pytania, inni natomiast wydają się traktować młodszych z góry, wymagając od nich zupełnego podporządkowania i karząc za złamanie ustalonych przez siebie reguł. $Z$ powodu tak różnych postaw dorosłych wobec dzieci w książce można odnaleźć przykłady obecnych już w literaturze dotyczącej dzieciństwa różnych stylów wychowania, których początkowo wyróżniono trzy: autokratyczny, demokratyczny i liberalny, a później podział uzupełniono o styl niekonsekwentny (Wysocka, Ostafińska-Molik 2015: 58).

Liberalny styl wychowania można zauważyć w rodzinie Harry’ego, jednakże ten styl występuje tylko w stosunku do jednego dziecka - Dudleya. Dursleyowie są wobec niego bardzo pobłażliwi - spełniają jego wszystkie zachcianki, jak również tolerują i usprawiedliwiają jego wybryki, takie jak na przykład stosowanie przez niego przemocy fizycznej wobec matki w celu zdobycia cukierków. Model ten zakłada brak kontroli ze strony rodziców, co w konsekwencji może spowodować panowanie dziecka nad opiekunami oraz wymuszanie różnych swobód czy prezentów, a także zachowania wysoce egoistyczne i wykształcenie nieadekwatnie wysokiego poczucia własnej wartości (Wysocka, Ostafińska-Molik 2015: 60). Dudley jest książkowym przykładem działania takiego modelu: udawanym płaczem wymusza troskę ze strony mamy, zdenerwowaniem z powodu zbyt małej liczby prezentów urodzinowych zmusza rodziców do zakupu kolejnych, zrzuca swoje obowiązki domowe na Harry’ego, przy czym wtórują mu faworyzujący go rodzice. 
Ciekawe jest to, że wobec drugiego dziecka, które wychowują, Dursleyowie wykorzystują zupełnie inną taktykę - styl autokratyczny. Zakłada on dystans między rodzicami (opiekunami) a dzieckiem oraz kompletny brak zainteresowania potrzebami młodej osoby. Od Harry’ego wymaga się bezwzględnego posłuszeństwa, a każde złamanie zasad karane jest zamknięciem chłopca w komórce pod schodami, która służy również jako jego pokój. Wychowywane w ten sposób dziecko żyje w ciągłym napięciu, co w konsekwencji może prowadzić do buntowniczej postawy wobec innych, szczególnie w sytuacji braku możliwości sprawowania kontroli przez opiekunów (Wysocka, Ostafińska-Molik 2015: 60). Normy, polecenia i zakazy traktuje jako coś narzuconego, w związku z czym w postępowaniu kieruje się bardziej własnym interesem i nie wytwarza emocjonalnej więzi z opiekunami, o czym Harry sam wspomina, opisując swojego wuja i ciotkę jako okropnych.

Inny styl wychowania występuje w rodzinie Weasleyów - przeważa tutaj styl demokratyczny, który uważany jest za najkorzystniejszy dla rozwoju dziecka. W tym modelu rodzice starają się mieć przyjacielskie stosunki ze swoimi dziećmi, cierpliwie wyjaśniać i argumentować istnienie reguł i zasad przy jednoczesnym ich egzekwowaniu. Przykładem takiego zachowania może być wyjaśnianie przez panią Wesley swojej najmłodszej córce, że obserwowanie kogoś nie jest grzeczne, bo druga osoba to również człowiek, a nie okaz w zoo.

W książce występują więc wszystkie trzy podstawowe style wychowania. Chciałabym jednak dodać, że w mojej opinii należy traktować je raczej jako pewne typy idealne, pojęcia ogólne (Weber Max), które pozwalają na umieszczenie konkretnego przypadku na pewnej skali. Nawet najbardziej liberalni opiekunowie mogą momentami sprawować większą kontrolę, a najbardziej surowi i wymagający czasem dają dziecku większy lub mniejszy wybór w pewnych kwestiach, w związku z czym stosowanie płynnych skali ma przewagę nad konkretnymi, zamkniętymi kategoryzacjami.

\section{Dyskryminacja dzieci w procesie wychowawczym}

Zanim jednoznacznie stwierdzimy, że dzieci są (lub nie są) dyskryminowane w procesie wychowawczym, powinniśmy określić, czym jest dyskryminacja. Na potrzeby tego eseju będę ją rozumieć za Baronem i Branscombe jako negatywne zachowania skierowane przeciwko członkom pewnych grup społecznych, wobec których występują uprzedzenia (2012: 194). Uprzedzenia z kolei oznaczają negatywne nastawienie w stosunku do członków tych grup (Baron, Branscombe 2012 : 203). Niechęć do dzieci i młodzieży nosi miano adultyzmu. Takie stanowisko opiera się na przeświadczeniu, że dorośli są od nich lepsi (Jankowiak 2017: 298, 300). Zjawisko to wiąże się także z nierównym udziałem uczestników we władzy. Warto dodać, że same uprzedzenia nie muszą wiązać się z ich wyrażaniem w zachowaniu; dyskryminacja za to może być opisana jako uprzedzenia, które przerodziły się w faktyczne działanie. Adultyzm może przejawiać się w wielu różnych zachowaniach, takich jak na przykład ukrywanie przed dzieckiem informacji 
ze względu na jego domniemaną niedojrzałość czy podejmowanie decyzji za młodych ludzi bez konsultacji z nimi (Jankowiak 2017: 298, 300).

W książce o Harrym Potterze występuje wiele przykładów dyskryminacji dzieci. Dursleyowie na przykład usilnie unikają tematu rodziców Harry’ego, jednakże to może także wynikać z ich ogólnej niechęci do nich. Hagrid - gajowy w Hogwarcie - również wielokrotnie nie chce udzielić Harry’emu i jego przyjaciołom pewnych informacji, a wręcz zakazuje im samodzielnie szukać odpowiedzi na niektóre pytania. Podobne unikanie trudnych pytań można zauważyć także u innych pracowników szkoły. Harry ze swoimi przyjaciółmi czują się zignorowani do tego stopnia, że w pewnym momencie zaprzestają jakichkolwiek działań w celu powstrzymania głównego antagonisty serii Lorda Voldemorta. O ich poczuciu niesprawiedliwości może świadczyć jedna z ich rozmów, w której dochodzą do wniosku, że nie mogą podzielić się swoimi odkryciami z żadnym z profesorów, bo "nie mają żadnych dowodów”, a więc "nikt im nie uwierzy”.

Dyskryminacja może przejawiać się także w występującej w tekście relacji władzy. To dorośli tworzą normy, zasady i regulaminy, których dzieci muszą przestrzegać, aby nie zostać ukarane. O ile niektóre z reguł są zasadne, na przykład zakazanie uczniom wchodzenia do niebezpiecznych miejsc, takich jak Zakazany Las, o tyle inne - zakaz wynoszenia książek z biblioteki, o której to zasadzie Harry nie wiedział, dopóki nie został ukarany za jej złamanie przez profesora Snape’a (i która to według Rona została wymyślona tylko po to, żeby Harry’ego ukarać) - służą jedynie podkreśleniu uprzywilejowanej pozycji profesora i ukazaniu władzy wobec uczniów. Warto wspomnieć, że Snape od samego początku nie darzy Harry’ego sympatią, a więc wydawać by się mogło, że rzeczywiście umyślnie wykorzystuje swoją pozycję, aby dokuczyć młodemu czarodziejowi. Innym przykładem tego zachowania są pierwsze zajęcia z eliksirów, na których Snape, pomimo tego, że do odpowiedzi zgłosiła się Hermiona, usilnie odpytuje Harry'ego tylko po to, aby upokorzyć go przed resztą grupy i pokazać mu, jak wiele jeszcze musi się nauczyć. Po tym poniżeniu Harry nie ma możliwości nawet stanąć w swojej obronie, bo skutkowałoby to ukaraniem go - jest więc z góry skazany na porażkę, znalazł się w podległej pozycji.

\section{Umacnianie dzieci w procesie wychowawczym}

Dyskryminacja nie jest jednak dominującym zjawiskiem w Hogwarcie. Wiele wskazuje na to, że większości profesorów obecnych w tej szkole zależy na dobrych wynikach w nauce uczniów, na ich bezpieczeństwie oraz dobrym samopoczuciu. Działania pozytywne, zorientowane na wspieranie dzieci można nazwać umacniającymi, a sam proces - umacnianiem.

Przykładów umacniania w książce jest wiele. Pierwszy z nich pojawia się na samym początku historii - tuż po tym, jak Harry dowiaduje się o swoich zdolnościach, zaczyna wątpić w swoje możliwości w kwestii edukacji magicznej, bo nigdy dotąd nie miał z nią styczności. Hagrid informuje go jednak szybko, że w szkole jest wielu uczniów takich 
jak on, oraz twierdzi, że na pewno da sobie radę. Zapewnia go także o swojej gotowości do pomocy w razie potrzeby, co dodaje Harry’emu otuchy, daje mu poczucie, że będzie miał na kogo liczyć. Kolejnym przykładem umacniania są wszystkie komplementy, jakie Harry otrzymuje w związku z jego znakomitymi występami w grze czarodziejów quidditchu. Pochwały te pochodzą od różnych osób - kolegów z tego samego domu ${ }^{1}$, przyjaciół, profesorów, a nawet od samego dyrektora. To wszystko sprawia, że główny bohater coraz bardziej wierzy w swoje umiejętności gry i wzrasta w nim pragnienie rozwijania tej nowej pasji, której poświęca bardzo dużo czasu. Ostatnim przykładem umacniania, jaki chciałabym opisać, jest radość, jaką pani Weasley okazuje swojemu synowi Percy’emu, któremu udało się zostać prefektem (odpowiednik starosty lub przewodniczącego klasy) Gryffindoru. Mama jest bardzo dumna z osiągnięcia swojego dziecka, rozmawia z nim czułym tonem i życzy mu dalszych sukcesów.

Umacnianie to bardzo ważny element wychowania dziecka. Pozwala młodej osobie na głębsze poznanie siebie, swoich mocnych stron, znalezienie hobby. Jeśli rodzic chce zachęcić dziecko do dalszego rozwoju lub poszukiwania pasji, musi pamiętać, że komplementowanie sukcesów jest dla młodego człowieka znacznie bardziej motywujące niż krytykowanie błędów, które może mieć skutek odwrotny i powodować, że dziecko zaprzestanie jakiejś aktywności. Najważniejszym jest jednak ogólne wsparcie, którym opiekun może obdarzyć swojego podopiecznego, a przede wszystkim konsekwentne utrzymanie tego wsparcia, także w momencie, w którym dziecko ponosi porażkę. Umacnianie może stanowić pewnego rodzaju fundament, na którym potem zbudowana zostanie samoocena młodego człowieka, dlatego ważne jest, aby ów fundament był bardzo solidny.

\section{Rola dorosłego w procesie wychowawczym}

Jak wspomniałam wcześniej, opiekun to do pewnego momentu najważniejsza osoba w życiu małego człowieka. Rodzic, będąc całym światem dziecka, ma więc bardzo trudne i odpowiedzialne zadanie. Przez wiele lat będzie bowiem pełnił wiele funkcji w życiu podopiecznego. To od rodzica zależy, jakim dorosłym stanie się kiedyś znajdujące się pod jego opieką dziecko.

Na podstawie omawianej książki wyróżniłam kilka funkcji, które może pełnić dorosły w procesie wychowawczym. Pierwszą rolą jest dorosły jako opiekun. Dosłownym przykładem zaczerpniętym z książki może być Hagrid ochraniający własnym ciałem Harry’ego i Hermionę przed nieznaną, zakapturzoną postacią, która pojawiła się znikąd podczas ich wyprawy do Zakazanego Lasu. W ten sposób zapewnia im poczucie bezpieczeństwa i służąc jako żywa tarcza, rekompensuje pewne braki umiejętności (na przykład samoobrony), których nie mieli jeszcze szansy się nauczyć. W tym momencie

1 W Hogwarcie istnieje podział na domy rywalizujące ze sobą co roku o Puchar Domów. Nowi uczniowie przydzielani są do Gryffindoru, Slytherinu, Hufflepuffu lub Ravenclawu. 
można zastanowić się, w jaki sposób dzieci mają taką umiejętność nabyć, skoro w momencie konfrontacji są wyręczani przez kogoś dorosłego, jednakże warto podkreślić, że zakapturzona postać - jak okaże się w ostatnim rozdziale książki - stanowiła realne zagrożenie dla życia Harry’ego i Hermiony, a więc zapewnienie ochrony przez Hagrida było w tym momencie słuszne.

Dorosły dla dziecka jest także nauczycielem. Młody człowiek przychodzi na świat i musi od razu zmagać się z uformowaną już w pewien sposób rzeczywistością. Nierozsądnym byłoby więc pozostawienie go samemu sobie i nakazanie samodzielnego zdobywania potrzebnej wiedzy i umiejętności; opiekun przekazuje więc dziecku swoją wiedzę o świecie w pigułce: są to normy i zasady, wiedza o organizacji społeczeństwa, tradycje, poglądy i sposób patrzenia na świat. Przykładów pełnienia przez dorosłych funkcji nauczyciela jest w książce wiele - wielu bowiem pracowników Hogwartu było na tyle otwartych, aby udzielić Harry’emu odpowiedzi na nurtujące go pytania, na przykład o jego rodziców. Oczywiście, zdarzały się także sytuacje, w których to odmawiano jemu lub innym dzieciom dostępu do informacji. Dlatego też warto być świadomym tego, że dorosły może wedle uznania zmniejszać lub zwiększać ilość przekazywanych informacji; to dziecko jest uzależnione od tego, co dorosły zechce mu ujawnić. Sama selekcja wiedzy, którą opiekun dostarcza podopiecznemu, jest już przejawem władzy, a władza ta - rodzic - ma prawo narzucać definicje dobra i zła, prawdy i fałszu. A zatem dorosły jako nauczyciel i dziecko jako uczeń wtłoczeni są w asymetryczną relację władzy.

Kolejną rolą, jaką dorosły może odgrywać w procesie wychowawczym, jest egzekwowanie przestrzegania zasad. Ta funkcja łączy się ściśle $\mathrm{z}$ dwoma poprzednimi: po przekazaniu wiedzy w postaci norm dorosły musi stać na straży zasad. Robi to na przykład po to, aby ochronić dziecko przed różnymi zagrożeniami, których może nie być ono świadome. Jednakże niektóre zasady mogłyby nie być potrzebne, gdyby młody człowiek był poinformowany o skutkach swoich działań. Wszystko to więc zależne jest od wiedzy, jaką dorośli przekażą dziecku, i od tego, w jakim stopniu pozwolą mu na niezależność.

\section{Podsumowanie}

Harry Potter i kamień filozoficzny to, moim zdaniem, książka o dużym potencjale edukacyjnym, i to nie tylko dla dzieci. Czytając powieść po raz kolejny, już jako osoba dorosła, dostrzegłam w niej wiele mechanizmów i zjawisk obecnych w procesie wychowawczym. Dyskryminacja dzieci, ich podporządkowanie czy uprzedmiotowienie to tylko kilka $\mathrm{z}$ tych, które udało mi się znaleźć w książce. Jest to dość smutna diagnoza społeczna, choć należy pamiętać, że książka ta ma już ponad dwadzieścia lat. Mimo to warto jednak przeczytać tę powieść z pewnego rodzaju refleksyjnością i świadomością, że opisane zjawiska mogą mieć bardzo negatywny wpływ na młodych ludzi.

Szczególnie zgubną wydaje się relacja władzy pomiędzy dorosłym a dzieckiem. Młoda osoba w momencie narodzin nie posiada pełnej wiedzy o świecie i właśnie z tego powodu jest bezbronna. Zadaniem opiekuna jest więc uzbrojenie dziecka w informacje tak, aby 
po początkowym etapie życia uniezależniło się od niego i mogło razem z dorosłymi na równych zasadach uczestniczyć w życiu społecznym. Ostatecznie to opiekun wybiera, czy chce być dla dziecka surowym strażnikiem zasad i znakiem zakazu, czy wręcz przeciwnie - woli pozwolić mu eksplorować świat i pełnić funkcję znaku informacyjnego, przewodnika i partnera w podróży zwanej życiem.

\section{Bibliografia}

Baron R.A., Branscombe N.R. (2012). Social Psychology, 13th Edition. Pearson, Kansas.

Jankowiak B. (2017). Adultyzm - uprzedzenia przeciwko młodym ludziom. „Studia Edukacyjne", 46: 297-305.

Rowling J.K. (2000). Harry Potter i kamień filozoficzny, tłum. A. Polkowski. Media Rodzina, Poznań.

Weber Max (b.d.w.). W: Encyklopedia PWN; https://encyklopedia.pwn.pl/haslo/Weber-Max;3994479. html (dostęp: 6.01.2020).

Wysocka E., Ostafińska-Molik B. (2015). Zaburzenia przystosowania młodzieży a style wychowania $w$ rodzinie. „Pedagogika Społeczna”, 4 (58): 55-79. 